\title{
A case of congenital anosmia
}

\section{Figure MRI findings of congenital anosmia}
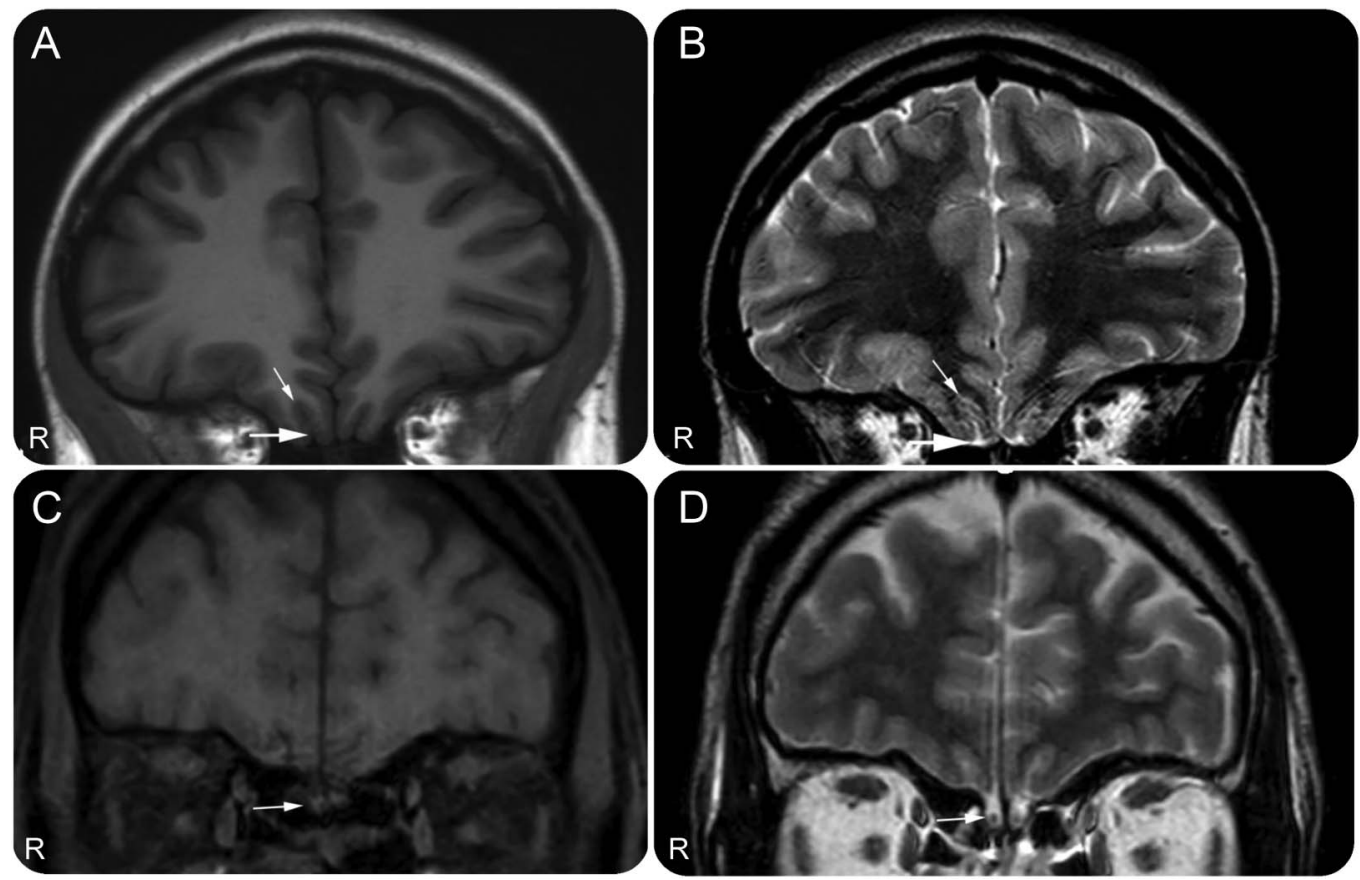

(A) Coronal T1 and (B) Coronal T2 MRI show absence of the olfactory bulbs in olfactory groove (thick arrows) with well-developed olfactory sulci (thin arrows). Normal (C) T1 and (D) T2 MRI from an age-matched girl for comparison show presence of olfactory nerves (white arrow).

An 18-year-old girl presented with inability to smell from birth. She had no symptoms to suggest an endocrine disturbance. Anosmia was confirmed on bedside testing. A diagnosis of congenital anosmia was made. A 3T MRI scan (figure) of this patient revealed no olfactory bulbs but developed olfactory sulci. The rest of the brain including corpus callosum was normal. The differential diagnosis for congenital anosmia is Kallman syndrome. However, in Kallman syndrome, the olfactory sulci would also be absent.

Umesh Vivekananda, MA, MBBS, MRCP, Nader Khandanpour, MD, PhD, FRCR, Salah Omer, MBBS, FRCP From St. George's Hospital, London, United Kingdom.

Author contributions: Umesh Vivekananda and Salah Omer contributed to the drafting and revision of the manuscript for content. Nader Khandanpour contributed to the acquisition of the MRI and their interpretation.

Study funding: No targeted funding reported.

Disclosure: The authors report no disclosures relevant to the manuscript. Go to Neurology.org for full disclosures.

Correspondence to U.Vivekananda: umie@doctors.org.uk 


\title{
Neurology
}

\author{
A case of congenital anosmia \\ Umesh Vivekananda, Nader Khandanpour and Salah Omer \\ Neurology 2016;87;2384 \\ DOI 10.1212/WNL.0000000000003384
}

This information is current as of November 28, 2016

$\begin{array}{ll}\begin{array}{l}\text { Updated Information \& } \\ \text { Services }\end{array} & \begin{array}{l}\text { including high resolution figures, can be found at: } \\ \text { http://n.neurology.org/content/87/22/2384.full }\end{array} \\ \text { Subspecialty Collections } & \begin{array}{l}\text { This article, along with others on similar topics, appears in the } \\ \text { following collection(s): } \\ \text { Clinical neurology examination } \\ \text { http://n.neurology.org/cgi/collection/clinical_neurology_examination } \\ \text { MRI } \\ \text { http://n.neurology.org/cgi/collection/mri }\end{array} \\ & \begin{array}{l}\text { Information about reproducing this article in parts (figures,tables) or in } \\ \text { its entirety can be found online at: } \\ \text { http://www.neurology.org/about/about_the_journal\#permissions } \\ \text { Permissions \& Licensing } \\ \text { Information about ordering reprints can be found online: } \\ \text { http://n.neurology.org/subscribers/advertise }\end{array}\end{array}$

Neurology ${ }^{\circledR}$ is the official journal of the American Academy of Neurology. Published continuously since 1951, it is now a weekly with 48 issues per year. Copyright (O 2016 American Academy of Neurology. All rights reserved. Print ISSN: 0028-3878. Online ISSN: 1526-632X.

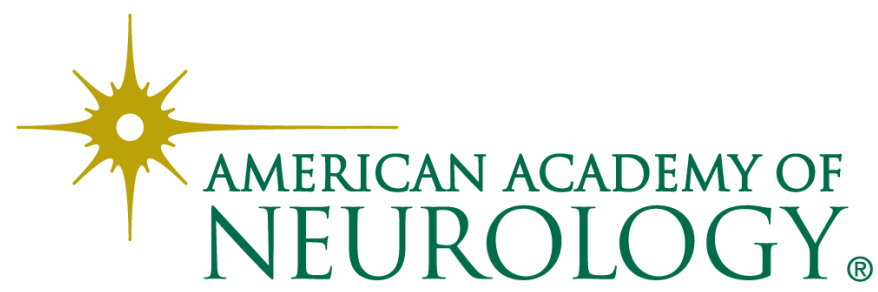

